Received : 2021-02-02 Revised : 2021-04-28 Acceptance : 2021-06-01 Publish : 2021-06-17

\title{
THE PROCESSING OF TOFU INDUSTRIAL WASTEWATER USING BIOCOAGULANT ALOE VERA GEL
}

\author{
Vita Kumalasari \\ Public Health Study Program, Stikes Surya Global Yogyakarta \\ *E-mail : vitastikessurga@gmail.com
}

\begin{abstract}
Tofu is a popular dish in Indonesia. If tofu production increases, it will also increase the produced waste. If the produced waste is not processed properly, it will cause environmental pollution which can cause health problems. One of the commonly used wastewater treatment methods is namely coagulationflocculation. Aloe vera functions as a biocoagulant because it contains complex carbohydrates and sugars that can bind particles in the water, and contains a coagulant active substance called as mucilago. This research is an experimental research using the One Group Pretest-Posttest Design research design. Samples of tofu industrial wastewater were taken from the home industry in Janten Village, Ngestiharjo Village, Kasihan, Bantul, DIY. The addition of aloe vera gel as much as $60 \mathrm{ml} / \mathrm{L}$ in the tofu industrial wastewater caused a decrease in $\mathrm{pH}$ by $11.19 \%$, COD $42.60 \%$, BOD $44.80 \%$ and increasing TSS by $8.85 \%$. It shows that aloe vera is effective to reduce COD and BOD in tofu industrial wastewater. Nevertheless, it is not effective to increase the $\mathrm{pH}$ of acidic tofu industrial wastewater and decreasing its TSS value.
\end{abstract}

Keywords : Biocoagulant, Aloe vera Gel, Tofu Industrial Wastewater

\section{INTRODUCTION}

Tofu is one of the most popular food in Indonesia because tofu contains high protein which comes from soybeans at a very affordable price. Most of tofu in Yogyakarta is produced by small and medium industries. The process of making tofu results solid, liquid and gas waste. Commonly solid waste which is called tofu dregs is reprocessed into tempe gembus, oncom and as animal feed. However, most of the tofu producers have not processed it due to several factors, such as the high cost, not having a large area to process it and lack of knowledge in wastewater management. In fact, the wastewater produced from the tofu-making process contains dissolved solid particles and suspended solids, most of which are organic substances. If wastewater is not processed, its wastewater will turn into blackish brown and cause a bad smell. If it is disposed without the correct treatment, it can contaminate groundwater and river water around the tofu making industry.

One of tofu industrial centers in Yogyakarta is in Janten village, Kasihan Bantul, Special Region of Yogyakarta. Here, a small industry uses soybeans as much as 14 quintals to 1 ton in a day to produce tofu, with $80,000 \mathrm{~mL}$ of wastewater produced. However, the wastewater produced is directly disposed into a ditch near the tofu production house. Even though, based on the results of laboratory examinations, the sample of wastewater shows the value of Total Suspended Solid (TSS), Chemical Oxygen Demand (COD), Biological Oxygen Demand (BOD) and $\mathrm{pH}$ are above the quality standard in the Regulation of 
the Minister of Environment of the Republic of Indonesia Number 52014 concerning to wastewater quality standards. Tofu industrial wastewater samples contained TSS of $395 \mathrm{mg} / \mathrm{L}$, COD of 6339,419 $\mathrm{mg} / \mathrm{L}$, BOD of $3790,972 \mathrm{mg} / \mathrm{L}$ and a $\mathrm{pH}$ of 4.2 . Whereas in the Regulation of the Minister of Environment of the Republic of Indonesia Number 5 of 2014 concerning to wastewater quality standards, the maximum permissible level for TSS is $200 \mathrm{mg} / \mathrm{L}$, COD is $300 \mathrm{mg} / \mathrm{L}$, BOD is $150 \mathrm{mg} / \mathrm{L}$, and pH is 69. If the wastewater is directly disposed of into the environment without any treatment first, it will clearly cause environmental pollution.

The most common method of water processing from physical to chemical is coagulationflocculation followed by sedimentation. Several types of inorganic coagulants that are widely used in processing the water include aluminum sulfate, iron sulfate, ferric chloride. Beside the inorganic coagulants, there are also local alternatives coagulants in the form of natural organic coagulants which are from plants and easily available. This natural coagulant is safer for human health and biodegradation. ${ }^{1}$ One of the natural coagulants is aloe vera. Aloe vera gel as a natural coagulant is able to purify the well water in Sausu Tambu Village, Sausu District because it contains an active coagulant substance called as mucilago. ${ }^{2}$ Aloe vera also contains complex carbohydrates and sugars which can bind particles in the water. ${ }^{3}$ Aloe vera as a biocoagulant can reduce COD in the oil industry by $262.15 \mathrm{mg} / \mathrm{L}$ (77.51\%), TSS by $99.75 \mathrm{mg} / \mathrm{L}(45.29 \%){ }^{4}$

Based on the background mentioned above, the researchers were interested in researching "The Processing of Tofu Industrial wastewater Using Biocoagulant Aloe Vera Gel".

\section{MATERIAL AND METHOD}

This research is an experimental research with a One Group Pretest-Posttest Design. wastewater samples were taken from tofu producers in Janten Village RT 10, Ngestiharjo Village, Kasihan Bantul, Special Region of Yogyakarta.

\section{Making Aloe Vera Gel}

The old Aloe vera leaves are stored at room temperature for 2-3 days. Then, those Aloe vera leaves are washed under running water to remove dirt and yellow latex. Peel the aloe vera skin and puree the flesh of aloe vera using a blender until it becomes a pulp. Strain the aloe vera pulp using a coarse sieve. The filtrate is ready to use as a biocoagulant.

\section{Water Processing}

Add $500 \mathrm{ml}$ of wastewater sample into a $1000 \mathrm{ml}$ erlenmeyer. Add $30 \mathrm{ml}$ and $60 \mathrm{ml}$ of aloe vera gel, then stir using a Jar Test at a speed of $120 \mathrm{rpm}$ for 1 minute. Continue stirring at $30 \mathrm{rpm}$ for 20 minutes and set aside for 60 minutes. Filter the supernatant and analyze the pH, TSS, COD and BOD levels.

\section{a. $\mathbf{p H}$}

\section{RESULTS AND DISCUSSION}

The $\mathrm{pH}$ of tofu industrial wastewater before adding aloe vera gel was 4.2. However, the average $\mathrm{pH}$ was 3.73 after adding aloe vera gel. The aloe vera gel which is added actually makes the $\mathrm{pH}$ of the tofu industrial wastewater more acidic. It is caused by the natural $\mathrm{pH}$ of aloe vera is 3.5-5.5. Based on laboratory tests, the $\mathrm{pH}$ of the aloe vera gel used in this study is 5 . The $\mathrm{pH}$ of 
aloe vera which is in acidic condition causes the $\mathrm{pH}$ of tofu industrial wastewater becomes more acidic after adding aloe vera gel.

\section{b. TSS}

Suspended material (unable to settle) in the water can be inorganic and organic particles. The inorganic materials can be in the form of mud, clay and other soil components which are commonly found in the water. Organic materials can be in the form of plant fibers and biological solids (algal cells, bacteria, etc.) which are also commonly found in the water. In general, TSS in industrial wastewater is as many as $40-65 \% .^{6}$ There are two characteristics of tofu industrial waste, namely physical and chemical characteristics. The chemical characteristics include organic materials, inorganic materials and gases. The organic materials contained in tofu industrial waste are generally very high. ${ }^{7}$ Aloe vera has many monosaccharides, polysaccharides and lipids; vitamins B1, B2, B6, and C; niacinamide and choline, some inorganic substances, enzymes (acid and alkaline phosphatase, amylase, lactic dehydrogenase, lipase) and organic compounds (aloin, barbaloin, and emodin). ${ }^{8}$

Based on the laboratory examinations, the TSS results before being added aloe vera gel were $395 \mathrm{mg} / \mathrm{L}$ and after being added aloe vera gel is an average of $433.33 \mathrm{mg} / \mathrm{L}$. The increase in TSS value was due to the very high content of organic matters in the tofu industrial wastewater and the organic material content inside the aloe vera gel in that the TSS value does not meet the standards set based on PermenLH RI Number 5 of 2014, which is $200 \mathrm{mg} / \mathrm{L}$. It shows that aloe vera gel is not effective in reducing TSS value in tofu industrial wastewater.

\section{c. COD}

COD is the determination of the oxygen level needed for chemical oxidation in a waste. In anaerobic waste processing, COD can be reduced to $9 \%$ in thermophile conditions (temperature $55^{\circ} \mathrm{C}$ ) and mesophyll conditions, COD can be reduced to less than $13 \%$. The diversity of organisms will also be able to accelerate the reduction of COD. ${ }^{9}$ The more precise the $\mathrm{pH}$ setting is given, the faster the suspended particles and organic compounds will be bound by alum molecules to form flocks. With the reduction of organic compounds and suspended in the wastewater, the need for oxygen to oxidize these compounds is reduced which results in a decrease in the COD value in tofu industrial wastewater. ${ }^{7}$

Based on the laboratory examination, COD results before being added aloe vera gel were 6,339,419 mg/L and after being added Aloe vera gel is an average of 3,638,630 mg/L. It shows that aloe vera gel is effective to reduce COD by $42.60 \%$.

\section{d. BOD}

The BOD value indicates that the amount of degraded organic matter biologically and by oxygen is used to oxidize inorganic materials such as sulfides and iron. Oxygen is also used to oxidize reduced nitrogen compounds. ${ }^{9}$ BOD (Biochemical Oxygen Demand) is a description of the amount of biodegradable organic matter (biodegradable organics) in the water ${ }^{10}$. Meanwhile, 
COD (Chemical Oxygen Demand) is the amount of oxygen needed to break down all organic matters contained in the water. It shows that if COD has decreased, BOD will also decrease because the organic material described in BOD is also broken down in COD. BOD breaks down organic matter which is easily broken down while COD breaks down organic material which is easy to break down and which is complex and difficult to break down. ${ }^{10}$

Based on the laboratory tests, the BOD results before being added aloe vera gel were $3,790,972 \mathrm{mg} / \mathrm{L}$ and after being aloe vera gel is an average of 2,044,910 $\mathrm{mg} / \mathrm{L}$. It shows that aloe vera gel is effective to reduce BOD by $44.80 \%$.

\section{CONCLUSION}

Aloe vera gel with a concentration of $60 \mathrm{ml} / \mathrm{L}$ is effective to reduce COD and BOD in tofu industrial wastewater. Aloe vera gel can reduce COD by $42.60 \%$ and BOD by $44.80 \%$. Aloe vera gel has an acidic $\mathrm{pH}$ making it suitable for treating alkaline waste.

\section{REFERENCES}

1. Suryani, Lilis, Upaya Preventif penyakit Water Borne Disease Pada Masyarakat Paska Gempa Yogyakarta, Jurnal Berdikari, Vol.5 No. 2 Agustus (2017). https://doi.org/10.18196/bdr.5228.

2. Mujariah, Paulus H. A., Minarni R. J., Penggunaan Gel Lidah Buaya (Aloe vera) sebagai Koagulan Alami dalam Penjernihan Air Sumur di Desa Sausu Tambu Kecamatan Sausu, Jurnal Ilmiah, Vol 5 No 1 Hal 16-22 (2016).

3. Pichler, T., Young, K., \& Alcantar, N, Eliminating Turbidity in Drinking Water Using The Mucilage of a Common Cactus, Water Science \& Technology: Water Supply, 179-186 (2012).

4. Puspita Dara, dkk, Penggunaan Lidah buaya sebagai biokoagulan di industri minyak, Surabaya : dalam conference Proceeding on Waste Treatment Technology ISSN No. 26231727 (2018).

5. Theodore J.D.P., et al, Coagulants and Natural Polymers: Perspective for the treatment of water.2, s.1. : Plastic and Polymer Technology (PAPT),179-186 (2013).

6. Saptati N.H, Dwi dan Nurul F. Himma, Perlakuan Fisiko-Kimia Limbah Cair Industri, UB Press, Malang (2018).

7. Coniwanti, P, dkk, Pengaruh Beberapa Jenis Koagulan Terhadap Pengolahan Limbah Cair Indutri Tahu Dalam Tinjauannya Terhadap Turbidity, TSS, dan COD, Jurnal Teknik Kimia No. 3, Vol. 19 Agustus 2013.

8. Rajin, Mukhamad, Manfaat Lidah Buaya Sebagai Obat Herbal Pendamping Infeksi Kuman Tuberkulosis, Universitas Pesantren Darul U'lum, Jombang (2019).

9. Hidayat, Nur, Bioproses Limbah Cair, ANDI OFFSET, Yogyakarta (2016).

10. Atima, Wa, BOD dan COD sebagai Parameter Pencemaran Air dan Baku Mutu Air Limbah, Jurnal Biology Science \& Education. Vol 4 No.1 DOI: http://dx.doi.org/10.33477/bs.v4i1.532. 